УДК 347.132

DOI: 10.33764/2687-041X-2021-1-90-93

\title{
УПОРЯДОЧЕНИЕ ПРОЦЕССОВ ОФОРМЛЕНИЯ ПРАВ НА ЗЕМЕЛЬНЫЕ УЧАСТКИ В РЕСПУБЛИКЕ БЕНИН
}

\section{Темилола Кредо Седрик Банколе}

Московский государственный университет геодезии и картографии, 105064, Россия, г. Москва, Гороховский переулок, 4, обучающийся, тел. (916)420-25-13, e-mail: bankole.credo@mail.ru

\section{Александр Павлович Сизов}

Московский государственный университет геодезии и картографии, 105064, Россия, г. Москва, Гороховский переулок, 4, доктор технических наук, заведующий кафедрой кадастра и основ земельного права, тел. (906)716-27-10, e-mail: ap_sizov@mail.ru

В статье рассмотрены процедуры получения документа на право собственности на землю в Республике Бенин и возникающие проблемы на каждом этапе. На основе проведенного исследования авторами предлагаются некоторые меры, чтобы избавиться от различных проблем, связанных с этой процедурой и обеспечить эффективное установление земельного кадастра в Республике Бенин.

Ключевые слова: землеустройство, Республик Бенин, право собственности, кадастр

\section{STREAMLINING PROCESSES FOR REGISTERING LAND RIGHTS IN THE REPUBLIC OF BENIN}

\section{Temilola Creed Cedric Bankole}

Moscow State University of Geodesy and Cartography, 4, Gorokhovsky Lane, Moscow, 105064, Russia, Student, phone: (916)420-25-13, e-mail: bankole.credo@mail.ru

\section{Alexander P. Sizov}

Moscow State University of Geodesy and Cartography, 4, Gorokhovsky Lane, Moscow, 105064, Russia, D. Sc., Head of the Department of Cadastre and Foundations of Land Law, phone: (906)716-27-10, e-mail: ap_sizov@mail.ru

This article discusses the procedures for obtaining a document on land ownership in the Republic of Benin and the problems encountered at each stage. Based on the study, the author proposes some measures to get rid of various problems associated with this procedure and to ensure the effective establishment of a land cadastre (land Registry) in the Republic of Benin.

Keywords: land management, Republic of Benin, property right, land Registry

\section{Введение}

В Республике Бенин документ на право собственности является единственным документом, который предоставляет своему держателю право свободно распоряжаться своей землей. Закон № 2017-15 от 26 мая 2017 года “Земельный кодекс Республики Бенин" по своему содержанию предусматривает довольно четкую процедуру с некоторыми мерами предосторожности и соответствующими положениями. Однако, нередки случаи, когда отсутствие пони- 
мания или недостаточное участие со стороны заявителей, а также некоторые административные ошибки создают определенные трудности при оформлении документа на право собственности $[1,2]$.

\section{Основные проблемы при составлении документ на право собственности в Республике Бенин}

Действительно, при выполнении процедуры инженер-геодезист может встретить следующие ситуации:

1. Заявительный этап. Ранее базовый топографический план, внесенный клиентом, был подписан присяжным-геодезистом. Государство, заметив, что, с одной стороны, геодезисты-присяжные подписывают базовый план, и, с другой стороны, должны проводить межевые работы (контрольное межевание) при составлении документа на право собственности, решило, чтобы облегчить задачу для населения и финансовое бремя, что подпись присяжногогеодезиста для базового плана больше не нужна. Достаточно, чтобы заявитель принес простой абрис своего земельного участка, и папка заявительных документов была принята.

Минусы этого решения в том, что теперь, когда геодезист-присяжный выполняет полевые работы, труднее найти участок или даже границы участка, потому что некоторые детали игнорируются на базовом плане.

2. Эman публичного запроса. Во время оповещения запроса на подтверждение прав на землю информирование делается судом, мэром и в официальной газете. Однако в настоящее время в Республике Бенине люди редко покупают газеты для чтения, и редко простой гражданин пойдет в мэрию или в суд просто для того, чтобы узнать, идет ли процедура подтверждения права на землю для какого-то человека.

3. Эman nолевых работ. Для подписания заключительного протокола по межевым работам (контрольное межевание) необходимо присутствие определенных действующих лиц (представитель мэрии, руководитель района, заявитель и смежники). Возможно, что некоторые акторы отсутствуют, потому что квитанции по оповещению не были во-время переданы.

Возможны специфические особенности местности [3]. Если на поле есть здания, которые могут скрыть некоторые границы земельного участка, то межевые работы могут быть приостановлены, если владельцы зданий не дают доступа для продолжения работ. Также возможно, что заявитель испытывает трудности с правильной идентификацией своего участка или информации, относящейся к его соседям, когда инженер уже на участке, это также замедляет межевые работы.

\section{Приложения}

Описанные трудности приводят к необходимости создания отдельной структуры, ответственной за улучшение процедуры подготовки документа на право собственности на землю и за содействие созданию будущего кадастра. 
В Республике Бенин человек, желающий получить документ на право собственности на землю, не всегда прилагает достаточные усилия. То же самое касается и управляющего имуществом, и нотариусов, которые слишком часто пренебрегают своей ролью. Поэтому было бы полезно реорганизовать систему путем создания отдельной структуры, которая конкретно занималась бы подтверждением прав на землю, созданием документа на право собственности и созданием наилучших условий для введения кадастра.

Единственная роль заявителя должна состоять в предоставлении заявительной папки и оплаты сбора за подготовку материалов.

Задачей присяжного-геодезиста является проведение межевания земель и составление протокола.

Указанная структура сделает остальные работы, чтобы облегчить процедуру подтверждения прав на землю перед началом работы присяжногогеодезиста. Действительно, остается решить следующие задачи:

1. Нанять техника-геодезиста, который должен на месте выполнить определенные проверки:

- проверить, есть ли новые соседи для земельного участка;

- проверить правильность ситуационного плана по земельному участку;

- проверить, есть ли новые постройки на земельном участке или вокруг него;

- сделать исследования по точной идентификации местоположения земельного участка;

- составить отчет, который будет вставлен в заявительную папку.

2. Указанная структура контактирует со всеми соседями и участниками в редактирования протокола, чтобы:

- взять их контакты;

- сообщить им об их задачах в процедуре;

- указать им день проведения межевания земель.

Исходя из важности документа на право собственности на землю, было бы полезно создать специальную бригаду для обеспечения контроля, чтобы власти и соседи выполняли свою роль в этом процессе. Действительно, можно применить финансовые санкции (штраф) всем тем, кто не выполняет свой долг.

3. По поводу публичности запроса структура может связаться со средствами массовой информации, чтобы:

- сделать объявления по радио;

- сделать пресс-релизы по телевидению;

- разработать специальные плакаты для публичных запросов о подтверждении прав собственности на землю.

Эта структура может также нанять молодых людей для публикации запроса о подтверждении прав собственности и тоже оповестить остальных граждан о важности документа на право собственности на землю. 


\section{Заключение}

В целом, совершенствование процедуры регистрации земли и эффективное создание кадастра в Республике Бенин требует больших усилий со стороны земельной администрации, чтобы исправить недостатки, обнаруженные во время процедуры получения документа на право собственности на землю. Также требуется приложить дополнительные усилия, чтобы люди поняли важность выполнения различных элементов, обеспечивающих получение документов на право собственности и ведение кадастра, объясняя им преимущества, которые они дадут. Целесообразно создание самостоятельной организационноштатной структуры, ответственной за создание земельного кадастра на основе улучшения процедуры создания документа о праве собственности на землю.

\section{БИБЛИОГРАФИЧЕСКИЙ СПИСОК}

1. Банколе Седрик Т.К. Геодезическое обеспечение работ по оформлению прав на землю в Республике Бенин: Выпускная квалификационная работа бакалавра // МИИГАиК, ФРТ. - 2018. - 76 с.

2. Банколе Улисс Б.Э. Научно-методические основы и методы создания автоматизированной информационной системы государственного кадастра в Республике Бенин с учетом экологических особенностей страны : Дисс. … к. т. н. по специальности 25.00.26Землеустройство, кадастр и мониторинг земель // МИИГАиК, ФРТ. - 2017. - 162 с.

3. Избранные проблемы и перспективные вопросы землеустройства, кадастров и развития территорий - 2017: колл. монография / колл. авторов; под общ. ред. А.П.Сизова. - М. : Изд-во «Русайнс». - 2018. - 262 с.

(C) Т. К. С. Банколе, А. П. Сизов, 2021 